\title{
Novel dermoscopic hexagonal pattern in chronic graft-versus-host disease
}

Running Head: Novel dermoscopic sign in chronic GVHD

Tom Kovitwanichkanont ${ }^{1}$ MBBS(Hons); Saurabh Prakash² MBBS, FRCPA; William C. Cranwell ${ }^{1,3}$ MBBS(Hons); Alvin H. Chong ${ }^{1,3}$ MBBS, FACD

${ }^{1}$ Transplant Dermatology Unit, Skin and Cancer Foundation Inc, Melbourne, Victoria, Australia

${ }^{2}$ Melbourne Pathology, Melbourne, Victoria, Australia

${ }^{3}$ Department of Dermatology, St Vincent's Hospital, Melbourne, Victoria, Australia

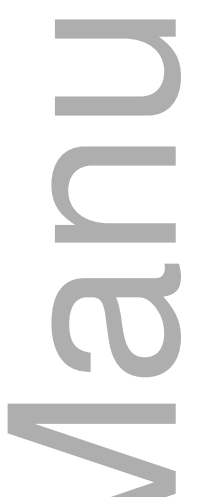

Contact information: Dr Tom Kovitwanichkanont; Skin and Cancer Foundation, 1/80

Drummond St, Victoria, Australia; tom.kovitwanichkanont@gmail.com; +61396239400

Conflict of interest: The authors declare that they have no conflict of interest.

Consent was obtained from the patient for publication of these clinical details and images.

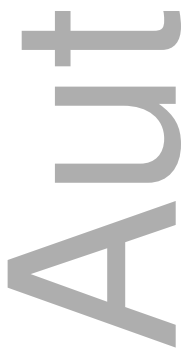

This is the author manuscript accepted for publication and has undergone full peer review but has not been through the copyediting, typesetting, pagination and proofreading process, which may lead to differences between this version and the Version of Record. Please cite this article as doi: $10.1111 /$ AJD.13109

This article is protected by copyright. All rights reserved 
DR. TOM KOVITWANICHKANONT (Orcid ID : 0000-0002-9270-3621)

DR. WILLIAM CHARLES CRANWELL (Orcid ID : 0000-0001-6368-5738)

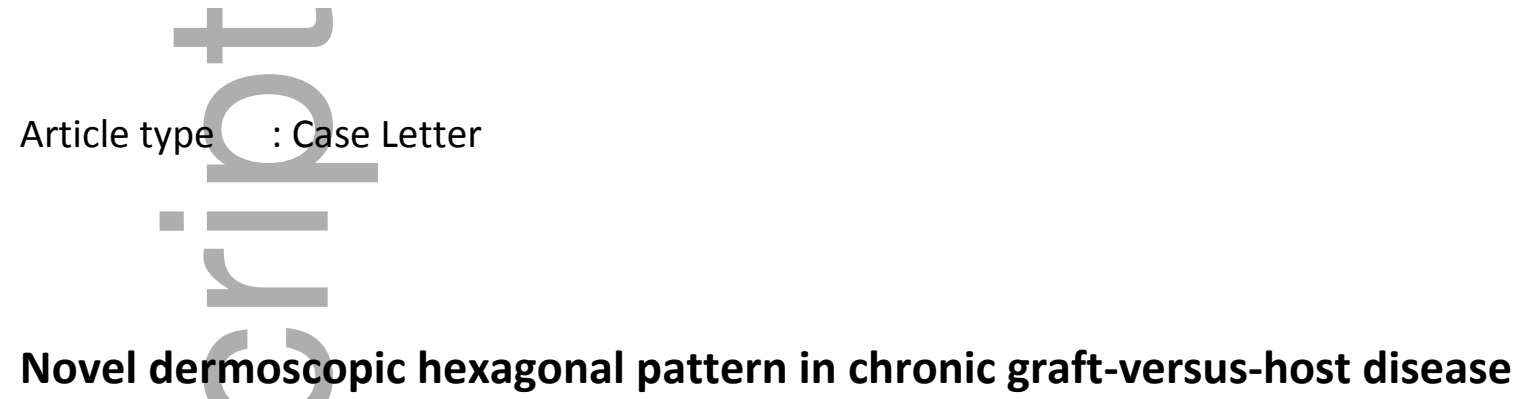

Graft-versus-host disease (GVHD) remains a major cause of morbidity and mortality following allogeneic haematopoietic stem cell transplantation (HSCT). The principal targets of GVHD include the skin, gastrointestinal tract, and liver. ${ }^{1}$ The late phase cutaneous manifestations of chronic GVHD include a disabling sclerodermatous skin reaction, including severe poikiloderma with widespread cutaneous sclerosis, contractions, focal ulceration, wasting and alopecia.

We report a 53-year-old man presenting for post-transplant skin surveillance, who underwent an allogeneic HSCT eighteen months prior from a matched sibling donor with fludarabine and melphalan conditioning for refractory T-cell prolymphocytic leukaemia. Within the first month following HSCT, he developed biopsy-confirmed acute cutaneous GVHD with mixed spongiotic and lichenoid reaction pattern. Other affected sites included pulmonary and ocular GVHD, necessitating immunosuppressive therapy with prednisolone $20 \mathrm{mg}$ daily and mycophenolate $1 \mathrm{~g}$ twice-daily. Over the eighteen months following HSCT, he developed chronic GVHD, complaining of increasing skin thickening, which was largely asymptomatic. Current topical therapy included betamethasone $0.5 \mathrm{mg} / \mathrm{g}$ cream daily to affected areas and regular emollients.

On examination, there were symmetrical induration of the skin of the limbs and trunk in discontinuous pattern on a background of diffuse poikiloderma. He also had a striking pattern of hyperpigmentation on his upper arms (Figure 1). Dermoscopic examination of these areas revealed a hexagonal pattern of grey-blue and brown dots (Figure 2). The

This article is protected by copyright. All rights reserved 
biopsies showed features of chronic GVHD involving the skin. Limited lichenoid changes are evident (Figure 3). The superficial dermis shows prominent melanin pigment incontinence (post-inflammatory type) (Figure 3), which would correlate with the dermoscopic appearance. There are sclerodermoid changes in the background dermis.

Dermoscopy is becoming an increasingly useful tool for assisting in the diagnosis of dermatoses beyond skin cancer. To date, only dermoscopic examinations of acute GVHD had been reported, which included a non-specific observation of linear vessels and multiple telangiectasia in acute GVHD patients. ${ }^{2}$ We report a novel dermoscopic description of hexagonal hyperpigmentation in the setting of chronic GVHD.

\section{References}

1. Hymes SR, Alousi AM, Cowen EW. Graft-versus-host disease: part I. Pathogenesis and clinical manifestations of graft-versus-host disease. J Am Acad Dermatol. 2012;66(4):515.e118; quiz 33-4.

2. Kaminska-Winciorek G, Czerw T, Kruzel T, Giebel S. Dermoscopic Follow-Up of the Skin towards Acute Graft-versus-Host-Disease in Patients after Allogeneic Hematopoietic Stem Cell Transplantation. BioMed research international. 2016;2016:4535717.

Figure 1: Macroscopic appearance of chronic cutaneous GVHD of the upper arm.

Figure 2: Dermoscopic examination demonstrating a hexagonal pattern of brown and grey dots.

Figure 3: Histological findings of chronic cutaneous GVHD demonstrating lichenoid changes and melanin pigment incontinence, correlating with the dermoscopic appearance. (H\&E staining, magnification $\times 200$ )

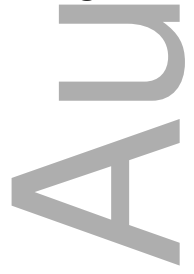

This article is protected by copyright. All rights reserved 


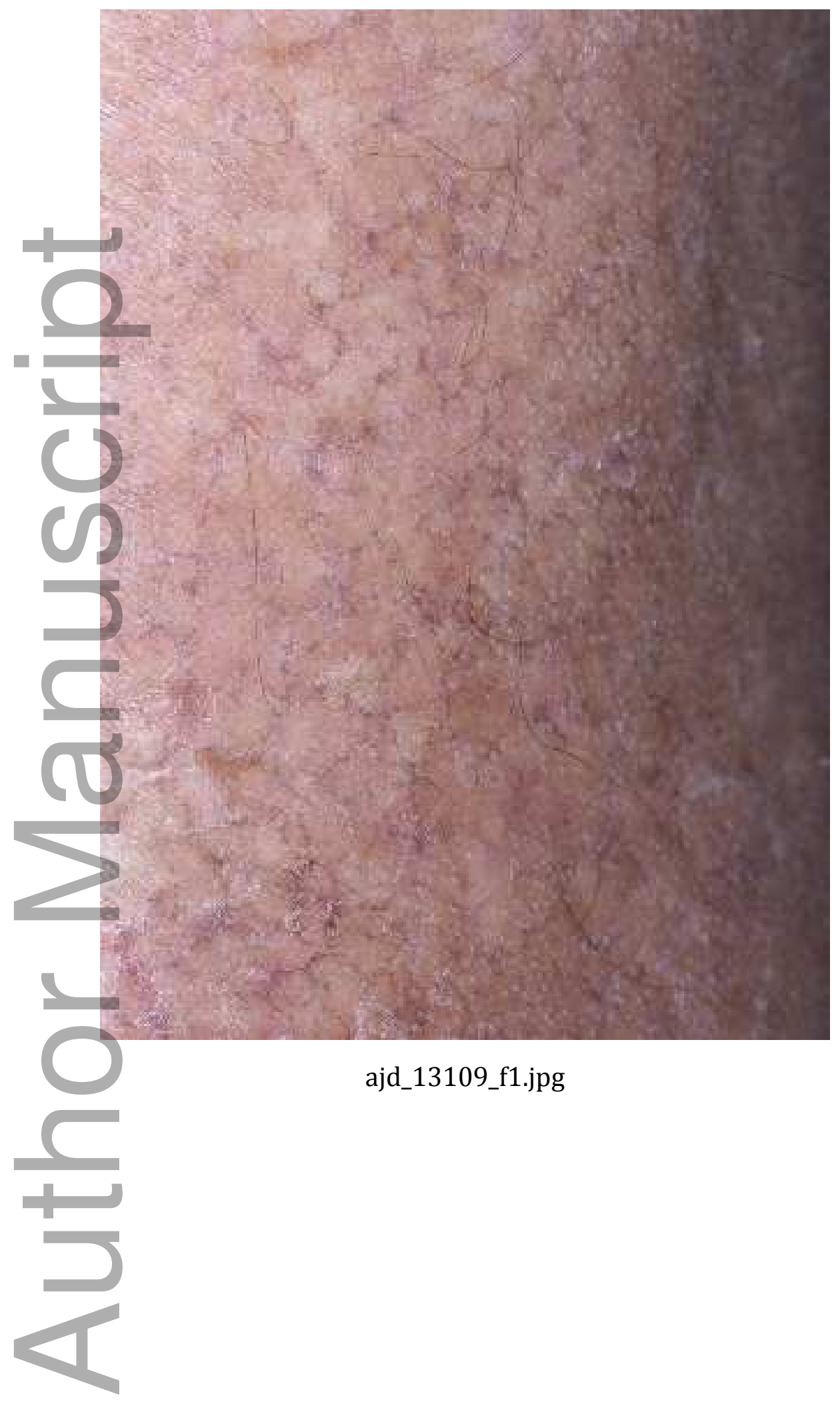

This article is protected by copyright. All rights reserved 


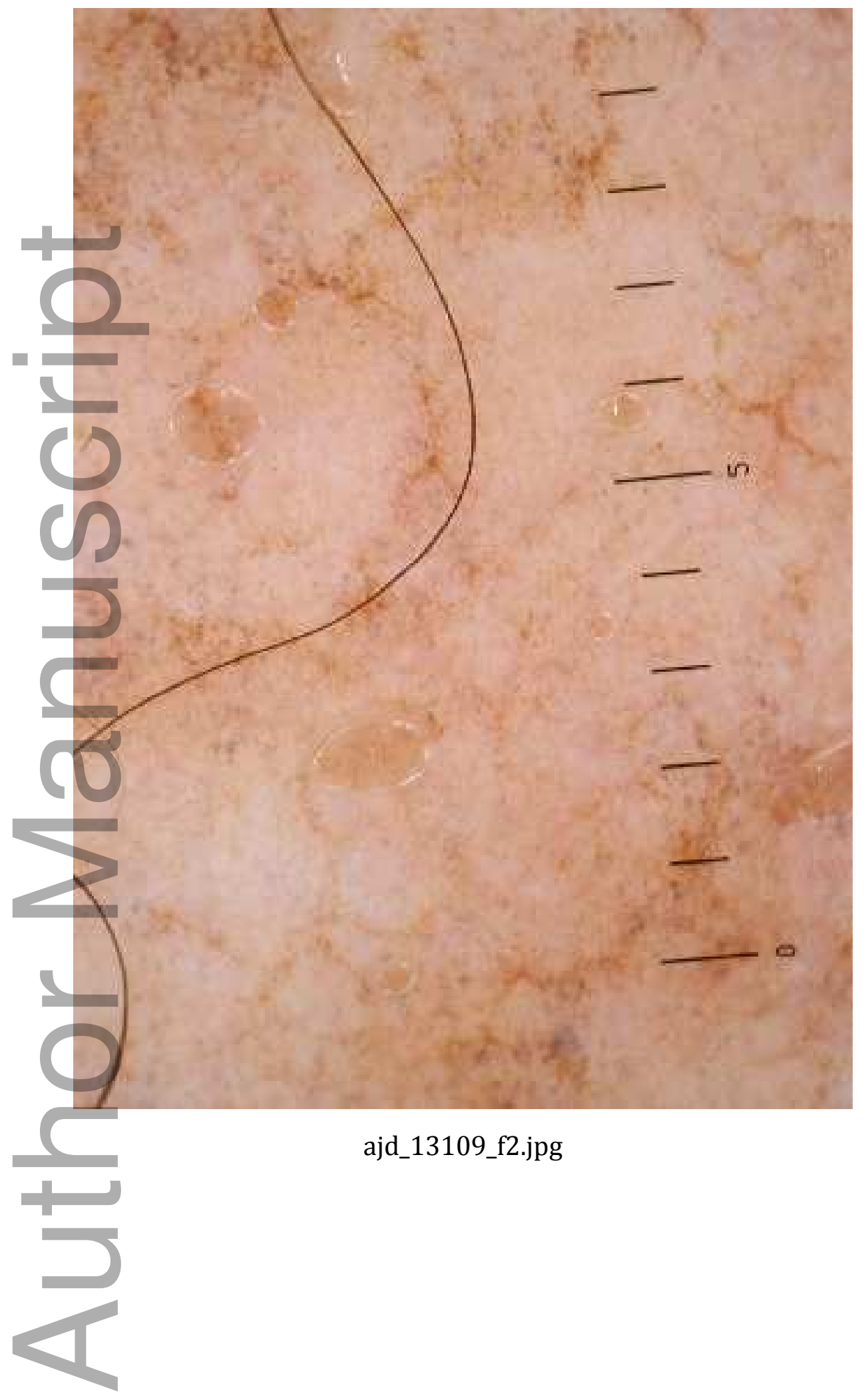

This article is protected by copyright. All rights reserved 

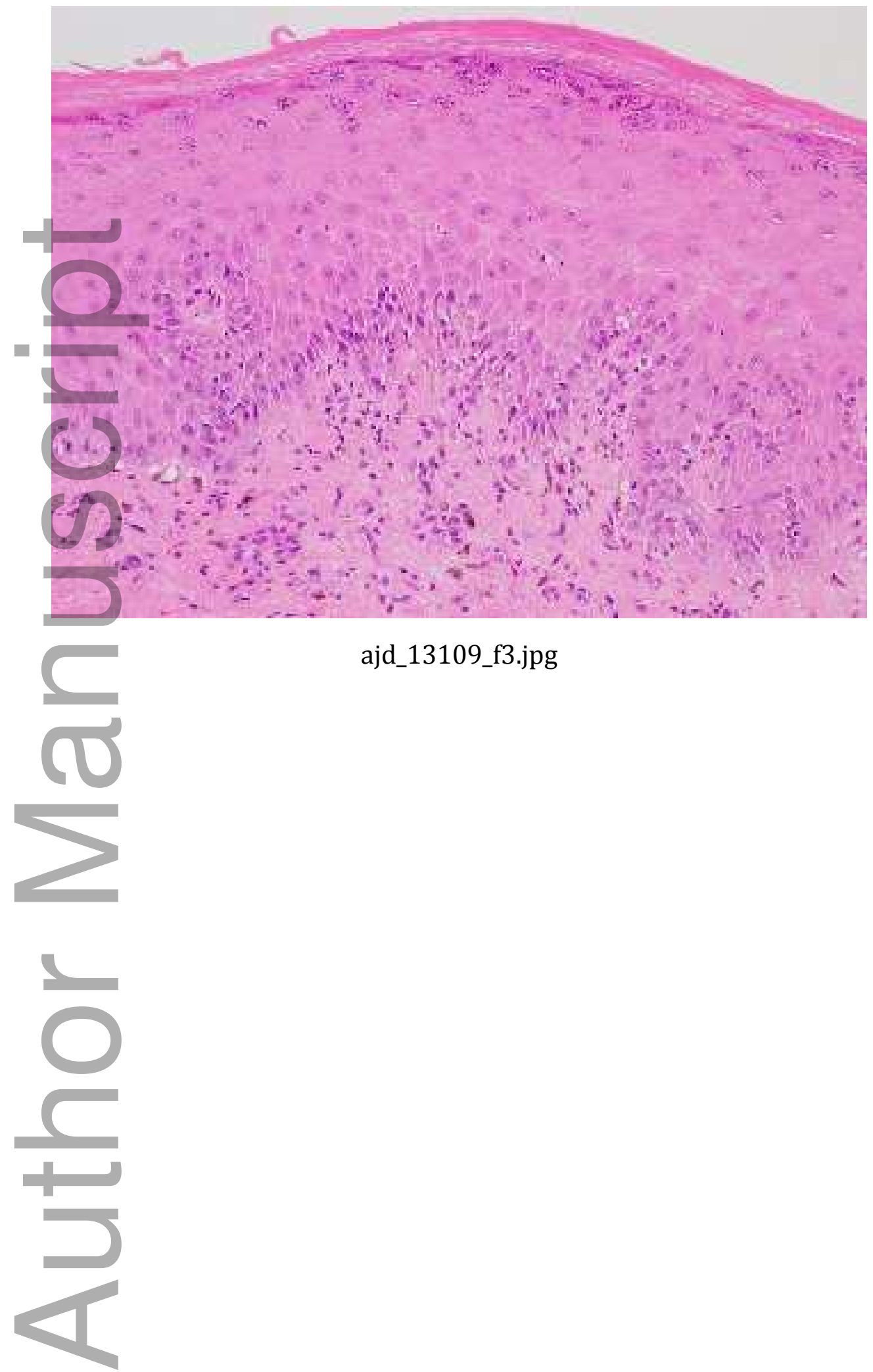

ajd_13109_f3.jpg

This article is protected by copyright. All rights reserved 


\section{University Library}

\section{- M M I N E R VA A gateway to Melbourne's research publications}

Minerva Access is the Institutional Repository of The University of Melbourne

Author/s:

Kovitwanichkanont, T;Prakash, S;Cranwell, WC;Chong, AH

Title:

Novel dermoscopic hexagonal pattern in chronic graft-versus-host disease.

Date:

2020-02

Citation:

Kovitwanichkanont, T., Prakash, S., Cranwell, W. C. \& Chong, A. H. (2020). Novel

dermoscopic hexagonal pattern in chronic graft-versus-host disease.. Australas J Dermatol, 61 (1), pp.e104-e105. https://doi.org/10.1111/ajd.13109.

Persistent Link:

http://hdl.handle.net/11343/286037 